\title{
Cytotoxic and genotoxic effects of perfluorododecanoic acid (PFDoA) in Japanese medaka
}

\author{
Isaac O Ayanda ${ }^{1,2, *}$, Min Yang ${ }^{2}$, Zhang $\mathrm{Yu}^{2}$ and Jinmiao $\mathrm{Zha}^{2}$ \\ ${ }^{1}$ Department of Biological Sciences, Covenant University, Ota, Ogun State, Nigeria \\ ${ }^{2}$ State Key Laboratory for Environmental Aquatic Chemistry, Research Center for Eco-Environmental Sciences, Beijing, China
}

\begin{abstract}
This study investigated the cytotoxic and genotoxic potential of perfluorododecanoic acid (PFDoA), a perfluorinated carboxylic chemical (PFC) that has broad applications and distribution in the environment in Japanese medaka, Oryzias latipes. Micronucleus (MN) test and Comet assay were used for the toxicity study. Three groups of fish were exposed to $0.1 \mathrm{mg} / \mathrm{L}, 0.5 \mathrm{mg} / \mathrm{L}$ and $2.5 \mathrm{mg} / \mathrm{L}$ concentration of the chemical for 28 days. Another group served as control. Sampling of the fish blood and liver were done after days $1,4,7,14,21$ and 28 for analysis of different erythrocyte abnormalities and damage to DNA using the MN test and Comet assay respectively. Results showed that there was a significant time and concentration dependent increase $(p<0.05)$ in percent tail length of DNA and frequency of erythrocyte abnormalities. Nuclear abnormalities observed include micronucleus, fragmented apoptotic cells, lobed nuclei, and bean-shaped cells. Increase in induction of erythrocyte abnormalities and percent tail length of DNA peaked at days 14 and 7 , respectively, after which there was a gradual decline. The results indicate that sub-chronic exposure of PFDoA to Japanese medaka caused DNA damage with a simultaneous induction of different erythrocyte abnormalities.
\end{abstract}

\begin{abstract}
Keywords: Comet assay / micronucleus test / DNA damage / PFDoA / Japanese medaka
Résumé - Effets cytotoxiques et genotoxiques de L'acide perfluorododecanoique (Pfddoa) sur Le medaka. Cette étude a étudié le potentiel cytotoxique et génotoxique de l'acide perfluorodécanoïque (PFDoA), un produit chimique carboxylique perfluoré (PFC) qui a de vastes applications et une large distribution dans l'environnement sur le medaka, Oryzias latipes. Le test du micronoyau (MN) et le test Comet ont été utilisés pour l'étude de toxicité. Trois groupes de poissons ont été exposés à des concentrations de $0,1 \mathrm{mg} / \mathrm{L}, 0,5 \mathrm{mg} / \mathrm{L}$ et $2,5 \mathrm{mg} / \mathrm{L}$ du produit chimique pendant 28 jours. Un autre groupe servait de contrôle. Le sang et le foie du poisson ont été prélevés après $1,4,7,14,21$ et 28 jours pour l'analyse de différentes anomalies érythrocytaires et de dommages à l'ADN au moyen du test $\mathrm{MN}$ et du test Comet, respectivement. Les résultats ont montré qu'il y avait une augmentation significative $(p<0,05)$ de la longueur de la queue de l'ADN et de la fréquence des anomalies érythrocytaires en fonction du temps et de la concentration $(p<0,05)$. Les anomalies nucléaires observées comprennent des micronoyaux, des cellules apoptotiques fragmentées, des noyaux lobés et des cellules en forme de haricot. L'augmentation de l'induction d'anomalies érythrocytaires et le pourcentage de la longueur de la queue de l'ADN ont atteint un maximum aux jours 14 et 7 respectivement, après quoi il y a eu une baisse graduelle. Les résultats indiquent que l'exposition subchronique au PFDoA du medaka a causé des dommages à l'ADN avec une induction simultanée de différentes anomalies érythrocytaires.
\end{abstract}

Mots-clés : Test Comet / test du micronoyau / dommages à l'ADN / PFDoA / medaka

\section{Introduction}

The aquatic ecosystem is the final recipient of pollutants produced both naturally and from anthropogenic activities; and

*Corresponding author:

opeyemi .ayanda@covenantuniversity.edu.ng if these substances are allowed to accumulate and persist in the environment, life may become threatened (Fleeger et al., 2003). The aquatic environment of countries that are highly populated receive a large quantity of waste either directly from agricultural activities, industry and urban settlements or indirectly as a result of airborne emissions being deposited in the atmosphere and this 
can cause contamination of the water bodies with complex chemicals (Frenzilli et al., 2009).

One of the environmental pollutants of global concern is the perfluoroalkyl acids (PFAAs). The reason being that they are widely applied in fire retardants, lubricants, cosmetics and insecticides (Kennedy et al., 2004). The constituent compounds found in these chemicals have differing lengths of chain including perfluorooctanoic acid (PFOA, C8), perfluorodecanoic acid and perfluorododecanoic acid (PFDoA, C12). PFAAs are not easily degraded due to their high energy C-F bond. As a result, they are persistent in soil, water, humans and wildlife (Kennedy et al., 2004; Van de Vijver et al., 2007; Tao et al., 2008). According to Kennedy et al. (2004), experiments with animals have implicated PFDoA as the most toxic of all the 8-12 carbon chain length PFAAs, as such, environmental toxicologists and agencies have informed of the risk posed by this chemical to human populations and the environment at large.

Of the different carbon atom lengths of the perfluorinated organic chemicals, the PFOA and Perfluorooctane Sulfonate (PFOS) are the most widely studied. This is probably because of their surfactant and anti-wetting properties which makes them widely used in industrial products (Butenhoff et al., 2006; USEPA, 2006). However, opinion varies on the genotoxic status of these perfluorinated carboxylic chemicals (PFCs). It was reported by Yao and Zhong (2005) that PFOA induced micronuclei in HepG2 cells and caused DNA strand breaks. It also increased 8-hydroxydeoxyguanosine (8-OH$\mathrm{dG}$ ) and intracellular reactive oxygen species (ROS). Earlier, Takagi et al., 1991 reported that PFOA induced 8-OH-dG in the liver of rat while Abdellatif (2003-2004) reported that PFOA does not significantly induce $8-\mathrm{OH}-\mathrm{dG}$. PFOS was not reported to be genotoxic even though Kawamoto et al. (2008) reported that it induces a change in the potential of the membrane of paramecium, leading to an abnormal behavior in swimming. Due to these inconsistencies, Kawamoto et al. (2010) suggested the need to study PFOS and PFOA on different biological systems. Studying PFOA and PFOS alone in other living systems may not suffice as there are many other different carbon atoms of perfluorinated compounds. Hence, this study was designed to determine the genotoxic potential of PFDoA in the liver of Japanese medaka, Oryzias latipes.

PFDoA is used in the textile industry as a component of dye; as such easily find its way into the aquatic environment. Dyes are very visible when present in effluents and they can impact water aesthetics, turbidity and even the solubility of gas in the aquatic ecosystem receiving the effluents. Furthermore, certain water parameters are negatively impacted (Lanciotte et al., 2004). The hazardous potential of textile effluents to the health of man and ecosystems has raised serious concerns. This is because there are some toxic substances in textile effluent such as surfactants, additives, detergents and dyes which can be terarogenic, mutagenic or carcinogenic to a wide range of organisms (Vanhulle et al., 2008).

DNA damage is a key occurrence in carcinogenesis. Lord and Ashworth (2012) reported that DNA lesions occurring at specific genomic sites can cause changes in the sequence of nucleotide, resulting in mutagenesis and some other cellular responses. A sensitive, simple and well established test for identifying a wide spectrum of DNA lesions such as single and double strand breaks and alkali-labile sites in single cells is the
(Singh et al., 1988). Evaluation of the genotoxic potential of pollutants in the environment by analysing the DNA alterations in aquatic organisms has enjoyed wide acceptability, and it is a suitable method for detecting exposure in a broad range of species (Kolarević et al., 2011; Rocco et al., 2012; Sunjog et al., 2012; Vuković-Gačić et al., 2013). Because of its relevance as a very valuable fish biomarker, genotoxicity testing has been suggested to be a fundamental component of environmental risk assessment programmes (Van der Oost et al., 2003). Furthermore, the micronucleus (MN) assay has been widely used as an all-inclusive method for evaluating damage in chromosome, which is scored specifically in oncedivided binucleated cells containing micronuclei and other cell abnormalities. The frequency of micronuclei is a popular early cytotoxicity biomarker specifying chromosome breakage and/ or total loss of chromosome (Xin et al., 2014).

Many important reasons have contributed to the use of fish as indicator organisms in genotoxicity studies (Szefer et al., 1990; Visn-Jeftic et al., 2010). These include their position in the food webs, nutritive value to humans, ability to bioaccumulate toxic chemicals, sensitivity to low concentrations of mutagenic agents and even their aesthetic value. The kidney and liver are the major organs in animals for PFCs bioaccumulation (Hundley et al., 2006). Additionally, the liver is the primary target organ for PFCs toxicity (Seacat et al., 2003).

\section{Methodology}

\subsection{Fish specimen and chemical}

Matured female Japanese Madaka (O. latipes) embryos were hatched and raised for two months; first in large glass beakers, and thereafter, transferred into treatment tanks for acclimatization. The specimens had an average weight of $0.72 \pm 0.04 \mathrm{~g}$ and average length of $2.7 \pm 0.03 \mathrm{~cm}( \pm \mathrm{SD})$. The fishes were acclimatized in laboratory conditions using a continuous flow through system, where the water continually renews itself, waste and unused food flows out of the system. They were fed with commercial feed twice daily during this period. For this study, technical grade PFDoA was purchased. A stock solution of the chemical $(50 \mathrm{mg}$ in $1 \mathrm{~L}$ of distilled water), was prepared by dissolving in DMSO and mixing manually for $20 \mathrm{~min}$ and thereafter transferred into a sonicator for one hour to allow better dissolution of the chemical.

\subsection{In vivo exposure}

After a two week acclimatization period, they were exposed to three concentrations of PFDoA $-0.1,0.5$ and $2.5 \mathrm{mg} / \mathrm{L}$ prepared by taking the appropriate volumes from the stock solution of the chemical and making it up to $1 \mathrm{~L}$ using distilled water. Exposure was done as static renewal, with renewal done every $24 \mathrm{hr}$ under the conditions of $16: \mathrm{h}$ light: darkness. The toxicant was administered once every $24 \mathrm{hr}$ to ensure its freshness. The fishes were divided into three groups with three replicates, fifteen fish in each tank, and forty five in each group. Some specimens were maintained in dechlorinated tap water and these served as the negative control. For the positive control, liver cells from $O$. latipes were treated with 
$2500 \mu \mathrm{M}$ hydrogen peroxide for $30 \mathrm{~min}$. The values of both negative and positive control used were based on the average of DNA damage from six samples on the first day. The experiment ran for a period of 28 days harvesting at intervals of $1,4,7,14,21$ and 28 days. At each harvest, six fishes were sacrificed from each treatment group and from the positive and negative control for comparison, and their livers excised. Physicochemical parameters of the diluting water were monitored in this period.

\subsection{Micronucleus (MN) assay}

Blood samples from each group were collected by cutting the tails of the fish and taking blood in a heparinized microcapillary tube. The MN assay in erythrocytes was conducted following a modified version of the previously mentioned protocol (Udroiu, 2006). The peripheral blood erythrocytes from each fish were dropped onto three clean slides that were flattened by other slides to produce an evenly distributed blood smear, treated with a fixative (methanol) for $15 \mathrm{~min}$ at room temperature, air-dried, stained with $10 \%$ Giemsa in a phosphate buffer (PBS), washed twice with PBS and mounted. MN scoring was conducted on the cells that had been spread onto clean slides and air-dried. For micronuclei analysis, approximately 5000-8000 erythrocytes per concentration were observed at a $1000 \mathrm{X}$ magnification using an Olympus B50 fluorescence microscope. The frequencies of clearly outlined and typically shaped micronuclei in the peripheral blood erythrocytes were observed. The criteria, which were introduced by Fenech (2000), specified that scorable cells should be separate, easily distinguished and of approximately equal size. From this, the frequency of micronuclei was calculated and expressed as a percentage.

\subsection{Comet assay}

Alkaline Comet Assay was used to evaluate the genotoxicity of PFDoA in this experiment using a Trevigen Comet Assay Reagent Kit, USA for Single Cell Gel Electrophoresis Assay. Fish liver was chopped into pieces $\left(1-2 \mathrm{~mm}^{3}\right)$, allowed to settle for $5 \mathrm{~min}$ and aspirated to get rid of medium. 1-2 mL of ice cold $20 \mathrm{mM}$ ethylenediaminetetraacetic acid was added in $1 \mathrm{X}$ phosphate buffered saline PBS $\left(\mathrm{Ca}^{++}\right.$and $\mathrm{Mg}^{++}$free), tissue was minced into very minute pieces and left to stand for a period of $5 \mathrm{~min}$. The cell suspension was recovered, while preventing transfer of debris. Cells were counted, pelleted and suspended at $1 \times 105$ cells $/ \mathrm{mL}$ in ice cold $1 \mathrm{X}$ PBS $\left(\mathrm{Ca}^{++}\right.$and $\mathrm{Mg}^{++}$free $)$. Cells were combined at $1 \times 10^{5} / \mathrm{mL}$ with molten Low Melting Agarose, at $37^{\circ} \mathrm{C}$ at a ratio of $1: 10(\mathrm{v} / \mathrm{v})$ i.e. $50 \mu \mathrm{L}$ of cells in suspension at $1 \times 10^{5} / \mathrm{mL}$ and $500 \mu \mathrm{L}$ of molten agarose. From this, $50 \mu \mathrm{l}$ was immediately pipetted onto CometSlide. Where necessary, side of pipette tip was used to spread agarose/cells over the sample area,ensuring total coverage of the sample area. Slides were placed flat at $4{ }^{\circ} \mathrm{C}$ in the refrigerator for $10 \mathrm{~min}$. Thereafter, slides were immersed in $4{ }^{\circ} \mathrm{C}$ Lysis Solution overnight at $4{ }^{\circ} \mathrm{C}$. Excess buffer was drained from slides and immersed in freshly prepared Alkaline Unwinding Solution at $p H>13$. The slides were allowed to stand in the Alkaline Unwinding Solution for $1 \mathrm{hr}$ at $4{ }^{\circ} \mathrm{C}$. The slides were placed in electrophoresis solution and made to pass through electrophoresis at $21 \mathrm{~V}$ for $30 \mathrm{~min}$. Again, excess electrophoresis solution

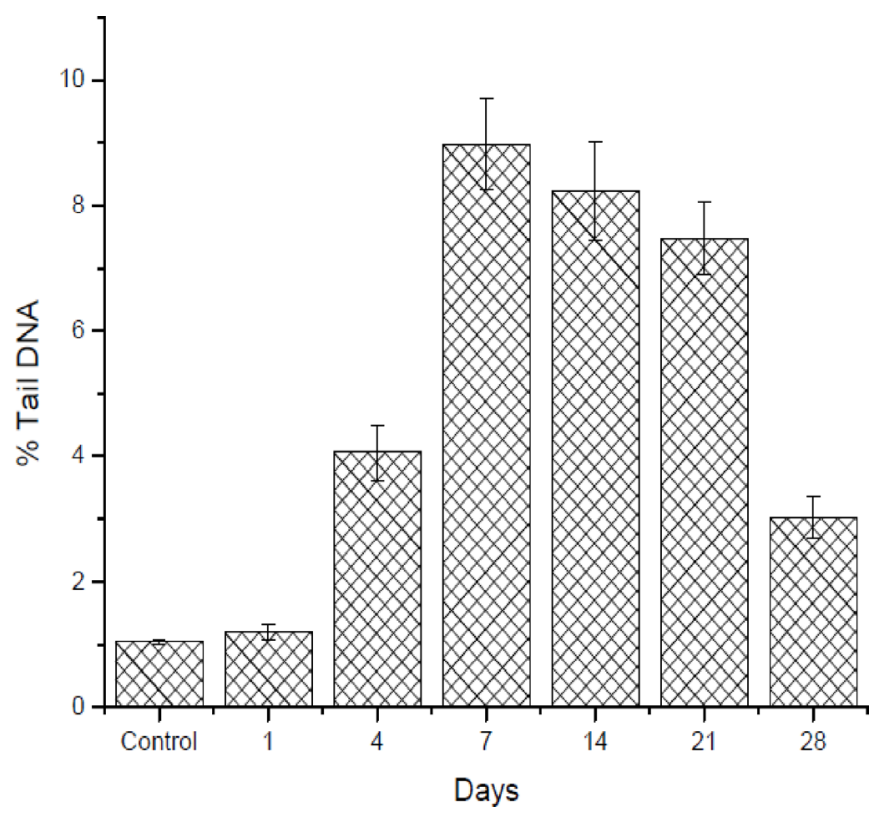

Fig. 1. Comparison of \% Tail DNA and time at concentration $0.1 \mathrm{mg} /$ L PFDoA.

was gently drained from slides, immersed two times in $\mathrm{dH}_{2} \mathrm{O}$ for $5 \mathrm{~min}$ each, and then in $70 \%$ ethanol for $5 \mathrm{~min}$. Samples were dried at $37^{\circ} \mathrm{C}$ for $10-15$ min to bring all the cells in a single plane for easier observation. $100 \mu \mathrm{L}$ of diluted SYBR Green was placed onto each circle of dried agarose and stained for $30 \mathrm{~min}$ at room temperature in the dark. Slides were tapped softly to remove excess SYBR solution and briefly rinsed in water. They were then allowed to dry completely at $37^{\circ} \mathrm{C}$. Six specimens per concentration were observed. For each specimen, two slides preparation was done, 20 cells per slide, totaling 240 cells per concentration, were randomly scored. DNA damage was analysed using Trevigen comet assay kit. The percentage tail of DNA was adopted as the parameter for quantifying DNA damage.

\subsection{Statistical analysis}

One-way analysis of variance was employed using SPSS software (Standard Version 10.0) to compare the differences between means in \% tail DNA in the different concentrations. Values were considered significant at $95 \%$ confidence level.

\section{Results}

Results of the physicochemical analysis of the test water used in the period of the experiment in the laboratory are as follows: Temperature - between 23.2 and $26.8^{\circ} \mathrm{C}, \mathrm{pH}-$ ranges from 6.04 to 7.14, Dissolved Oxygen - between 6.7 and $7.7 \mathrm{mg} / \mathrm{L}$, Conductivity - 238-290 $\mu \mathrm{s} \mathrm{cm}^{-1}$.

DNA damage, expressed as \% tail DNA was observed in the liver cells of fish in the period under observation. Each of the Figures 1-3 shows a time-dependent increasing damage in the DNA observed in fish liver cells after exposure to varying concentrations of PFDoA in the experiment. Nevertheless, damage to fish DNA was observed to be at the highest on day 7 


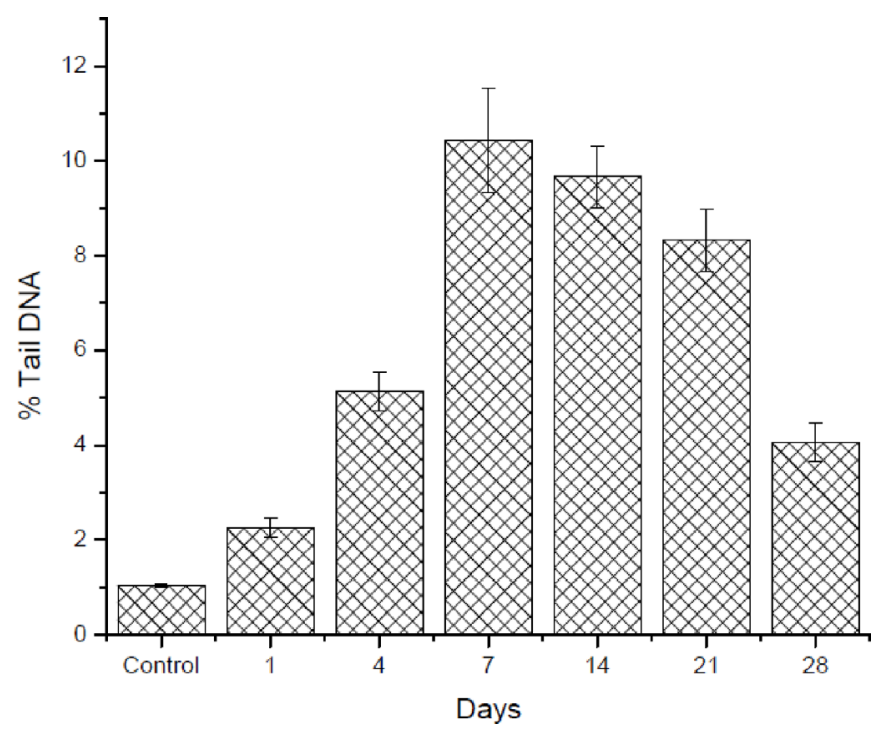

Fig. 2. Comparison of \% Tail DNA and time at concentration $0.5 \mathrm{mg} /$ L PFDoA.

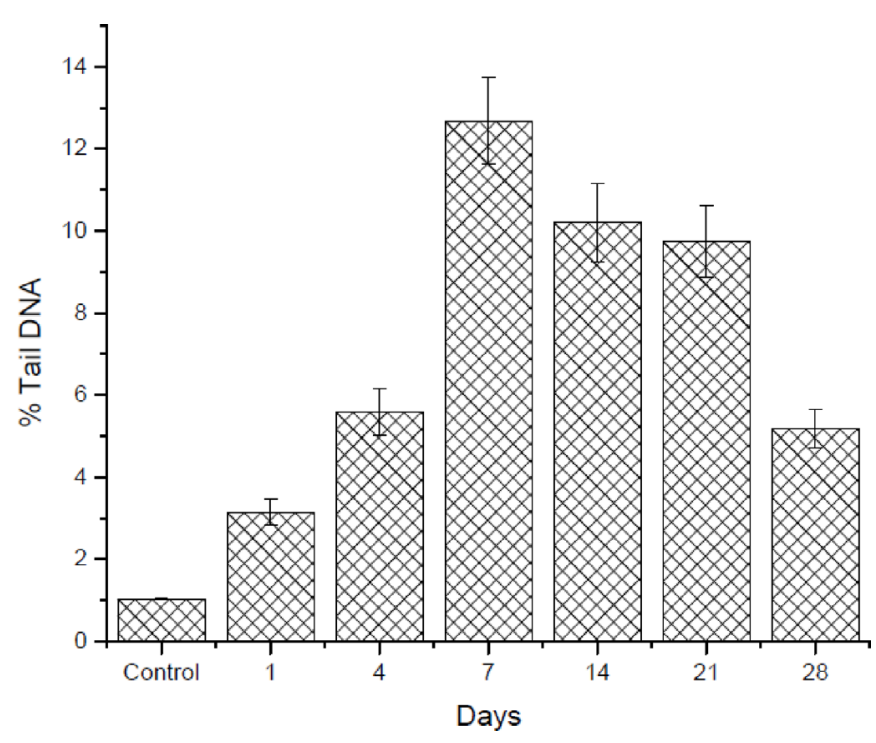

Fig. 3. Comparison of \% Tail DNA and time at concentration $2.5 \mathrm{mg} /$ L PFDoA.

in all the concentrations. After this period, DNA damaged was observed to reduce gradually. Also from the result, a concentration-dependent DNA damage was observed; the most pronounced damage noticed in the highest concentration. The tail length of DNA in fish exposed to the different concentrations of the chemical was higher in comparison with the values in the negative control. The positive control value also indicated a high degree of damage to fish liver cells. The respective values for the negative and positive control as calculated are $1.04 \pm 0.03$ and $6.15 \pm 0.12$. Some of the different comets observed are shown in Figure 4.

Similar to the results observed from the comet assay, PFDoA induced MN and some other cell abnormalities in fish blood. The frequency of MN and other forms of altered erythrocytes are presented in the table. Apart from MN, other nuclear alterations include lobed nuclei, fragmented apoptotic cells and bean-shaped nuclei. The different cell abnormalities did not show a consistent pattern of increase with time, however, total number of altered cells increased with increasing concentration till day 14 after which a decline was noticed. Furthermore, the frequency of altered cells increased with time.

Values with the same capital letter superscript, within the same week/fortnight are not significant while values with the same small letter superscript, against the same concentration are not significant $(p \geq 0.05)$. (Mean values \pm SE are for $n=12$ ) during the observation period. These increases were significant $(p<0.05)$ in comparison with the negative control. The total number of the different cell abnormalities counted in the erythrocytes of both the control and exposed fishes is also presented in the table. This chemical shows potential to be an environmental toxicant.

\section{Discussion}

Assessing toxicity is important in determining how sensitive animals are to toxic agents, and can be used to measure the extent of damage to target organs and the resultant behavioral, biochemical and physiological alterations (Nwani et al., 2010). That DNA damage is triggered off in the liver cells of $O$. latipes due to PFDoA exposure at different concentrations suggests its potential genotoxic and mutagenic properties. The negative control fishes had their DNAs intact, thus DNA damage can be said to be a result of the clastogenic action of the chemical. Environmental mutagen has been reported to increase both micronuclei and DNA migration in fish (Russo et al., 2004).

Damage to the DNA of fish liver in the negative control group, as compared with those treated with different concentrations of PFDoA is low; hence the greater damage observed in exposed fish could only have been as a result of the toxic action of the chemical suggesting it to be genotoxic. Promoting DNA damage has been reported to be the first mechanism of action of genotoxic agents, which can possibly result in three outcomes: the damage can be repaired, the damage can become irreversible, or the damage may lead to cell death (Vicari et al., 2012). According to Akcha et al. (2003), the absorption and biotransformation of genotoxic environmental pollutants could lead to the formation of DNA strand breaks in erythrocytes. Furthermore, the damage to fish DNA caused by PFDoA used in the present study might also have occurred due to the production of ROS. ROS such as hydroxyl radical $\left(\mathrm{OH}^{-}\right)$, superoxide anion $\left(\mathrm{O}_{2}^{-}\right)$and hydrogen peroxide $\left(\mathrm{H}_{2} \mathrm{O}_{2}\right)$, have been shown to produce damage such as strand breakage in DNA, enzyme inactivation and sometimes apoptosis (Peña-Llopis et al., 2003; Banudevi et al., 2006). Thus, it is possible that PFDoA could cause alterations in DNA of $O$. latipes resulting in formation of comets.

Reports from this study adds to public knowledge on the genotoxicity of the perfluorinated chemicals. As discussed above, the 8-carbon atoms of this group of compounds have been reported to both be genotoxic and non-genotoxic. There is the likelihood that PFDoA will also be toxic to previously studied living cells - human HepG2 and paramecium (and 


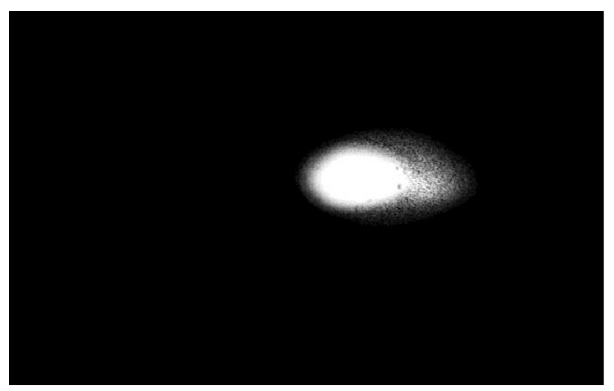

$\mathrm{c}$

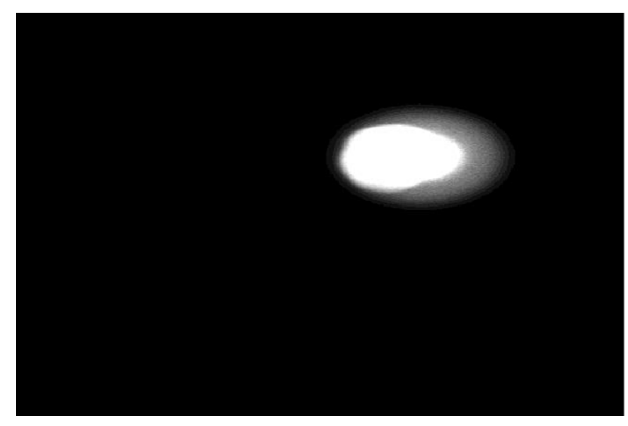

b

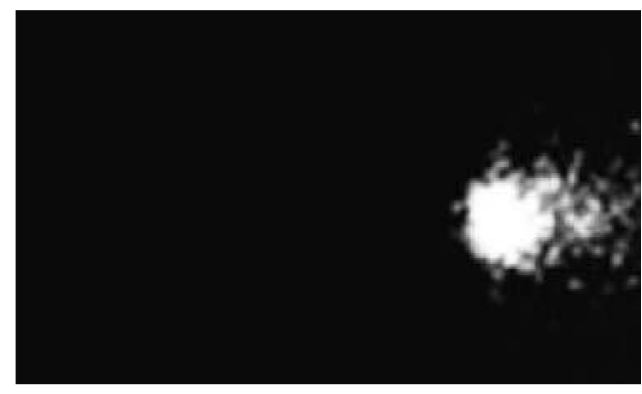

d

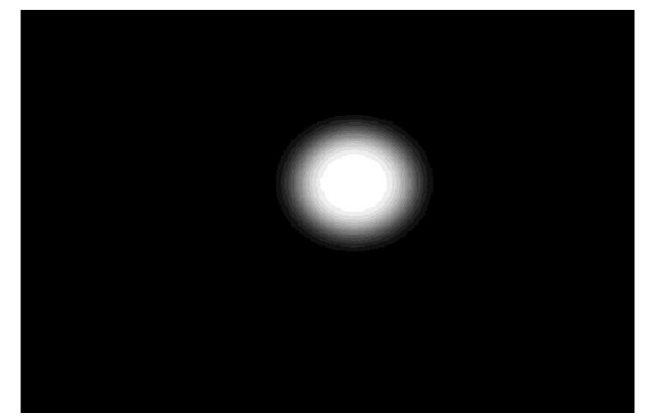

Fig. 4. Comets in fish DNA as a result of effects of PFDoA at concentrations (a) $0.1 \mathrm{mg} / \mathrm{L}$ (b) $0.5 \mathrm{mg} / \mathrm{L}$ (c) $2.5 \mathrm{mg} / \mathrm{L}$ and (d) $0.00 \mathrm{mg} / \mathrm{L}$.

even other aquatic organisms) as it has been reported to be the most toxic of all PFCs. However, it will be interesting to see if with time, future genotoxic studies on PFDoA will report otherwise.

The reduction of the comets in DNA as observed in the tissues of fishes after day 7 may indicate repair of damaged DNA, loss of heavily damaged cells, or both (Banu et al., 2001). The DNA repair systems may have led to this, and it could be explained using the threshold dependent repair theory. It proposes that the DNA repair enzymes get activated and that the rate of enzyme activity increases when a tissue accumulates toxicants above a threshold level, below which DNA repair operates only at a basal level (Ching et al., 2001). Furthermore, knowledge of this will be a good starting point for environmental impact assessors even though further studies may still be essential.

An essential strategy for realizing better insight into the ability of organisms to repair damaged DNA, and other protective mechanisms for excreting the toxic chemicals may be a long-term genotoxicity study. Moreso, the absence of tail DNA at longer exposure as observed in this study could also be due to other mechanisms like toxicity of the contaminant preventing the enzymatic process of DNA damage (Rank and Jensen, 2003).

The result of the present study has shown that PFDoA has ability to cause different cell alterations in Japanese medaka (Tab. 1). It also showed that these alterations could be dependent on time and concentration. This result is similar to those reported by different researchers on the effects of different environmental pollutants in fish. The occurrence of a greater number of MN and other nuclear abnormalities in the treated fishes compared with the control in this study provides evidence of the cytotoxic potential of PFDoA. This probably means the fishes were under toxic stress. Because $\mathrm{MN}$ is usually given off along with the main nucleus, their presence would suggest their origin at a cell cycle that is more recent (Chandra and Khuda-Bukhsh, 2004). According to Jerbi et al., (2011), the formation of micronucleated cells may be an indication of aneugenic and/or clastogenic actions, because the presence of $\mathrm{MN}$ can be related to entire chromosomes, caused by a malfunctioning of the spindle, or with chromosome fragments, derived from chromosome breakage.

This study showed progressive increase in the number of micronucleated erythrocytes and other abnormalities till day 14. This is in agreement with some (De Lemos et al., 2001; Cavas et al., 2005) studies that have reported decrease in the number of $\mathrm{MN}$ in fish erythrocytes after 14-21 of exposure. This could mean that DNA repair occurred after the day 14 onwards.

In conclusion, the present study has established the cytotoxic and genotoxic capability of PFDoA in fish. It also further proves the suitability of the $\mathrm{MN}$ and Comet assay as tools for evaluating potential environmental toxins. Because this chemical is a component of dye used in the textile industry, its hazardous potential to ecosystem and human health should be of great concern especially in countries with huge, active textile industry. The toxicity of the chemical to Japanese medaka provides a basis to project the potential harm that may be caused to other inhabitants of the ecosystem and those who depend on them. Therefore, it may be imperative to ensure careful, efficient use of this chemical so as to prevent adverse effects in the genetic components of aquatic ecosystems and man.

\section{Conflict of interest}

Authors declare that there is no conflict of interest in this research article. 
I.O. Ayanda et al.: Knowl. Manag. Aquat. Ecosyst. 2018, 419, 9

Table 1. Time course numbers and frequencies of different cell alterations caused by concentrations of perfluorododecanoic acid in Japanese medaka.

\begin{tabular}{|c|c|c|c|c|c|c|c|c|}
\hline \multirow{2}{*}{$\begin{array}{l}\text { Time } \\
\text { (days) }\end{array}$} & \multirow{2}{*}{$\begin{array}{l}\text { Conc } \\
(\mathrm{mg} / \mathrm{L})\end{array}$} & \multirow{2}{*}{$\begin{array}{l}\text { Total number of } \\
\text { cells scored }\end{array}$} & \multicolumn{4}{|c|}{ Alterations } & \multirow{2}{*}{$\begin{array}{l}\text { Total number of } \\
\text { Altered Cells }\end{array}$} & \multirow{2}{*}{$\begin{array}{l}\text { Frequency of } \\
\text { Altered Cells }(\%) \pm \text { S.E }\end{array}$} \\
\hline & & & $\mathrm{MN}$ & $\mathrm{LN}$ & FAC & B-SC & & \\
\hline \multirow[t]{4}{*}{1} & 0.00 & 6513 & 10 & 14 & 16 & 20 & 60 & $0.92 \pm 0.026^{\mathrm{Aa}}$ \\
\hline & 0.1 & 6798 & 15 & 23 & 23 & 21 & 82 & $1.21 \pm 0.019^{\mathrm{Ba}}$ \\
\hline & 0.5 & 7120 & 14 & 27 & 30 & 41 & 112 & $1.57 \pm 0.036^{\mathrm{Ca}}$ \\
\hline & 2.5 & 6907 & 20 & 37 & 31 & 26 & 114 & $1.65 \pm 0.025^{\mathrm{Da}}$ \\
\hline \multirow[t]{4}{*}{4} & 0.00 & 6645 & 11 & 12 & 15 & 23 & 61 & $0.91 \pm 0.017^{\mathrm{Aa}}$ \\
\hline & 0.1 & 7343 & 16 & 24 & 30 & 48 & 118 & $1.61 \pm 0.033^{\mathrm{Bb}}$ \\
\hline & 0.5 & 6578 & 28 & 28 & 29 & 27 & 112 & $1.70 \pm 0.028^{\mathrm{Cb}}$ \\
\hline & 2.5 & 6998 & 20 & 32 & 46 & 32 & 130 & $1.86 \pm 0.018^{\mathrm{Db}}$ \\
\hline \multirow[t]{4}{*}{7} & 0.00 & 6809 & 12 & 13 & 18 & 19 & 62 & $0.91 \pm 0.031^{\mathrm{Aa}}$ \\
\hline & 0.1 & 6787 & 20 & 30 & 37 & 34 & 121 & $1.78 \pm 0.040^{\mathrm{Bc}}$ \\
\hline & 0.5 & 7155 & 20 & 43 & 42 & 35 & 140 & $1.96 \pm 0.060^{\mathrm{Cc}}$ \\
\hline & 2.5 & 7483 & 24 & 46 & 37 & 44 & 151 & $2.02 \pm 0.023^{\mathrm{Cc}}$ \\
\hline \multirow[t]{4}{*}{14} & 0.00 & 6850 & 12 & 12 & 16 & 20 & 60 & $0.87 \pm 0.022^{\mathrm{Aa}}$ \\
\hline & 0.1 & 7140 & 34 & 38 & 31 & 31 & 134 & $1.88 \pm 0.013^{\mathrm{Bd}}$ \\
\hline & 0.5 & 7151 & 32 & 54 & 36 & 42 & 166 & $2.32 \pm 0.018^{\mathrm{Cd}}$ \\
\hline & 2.5 & 6583 & 30 & 54 & 51 & 42 & 167 & $2.54 \pm 0.030^{\mathrm{Dd}}$ \\
\hline \multirow[t]{4}{*}{21} & 0.00 & 5779 & 12 & 11 & 24 & 13 & 60 & $1.04 \pm 0.013^{\mathrm{Aa}}$ \\
\hline & 0.1 & 6782 & 20 & 40 & 27 & 25 & 112 & $1.65 \pm 0.028^{\mathrm{Bb}}$ \\
\hline & 0.5 & 7540 & 15 & 33 & 27 & 48 & 123 & $1.63 \pm 0.028^{\mathrm{Cb}}$ \\
\hline & 2.5 & 6987 & 21 & 35 & 58 & 28 & 142 & $2.03 \pm 0.022^{\mathrm{Db}}$ \\
\hline \multirow[t]{4}{*}{28} & 0.00 & 6556 & 13 & 16 & 23 & 12 & 64 & $1.02 \pm 0.025^{\mathrm{Aa}}$ \\
\hline & 0.1 & 6494 & 13 & 28 & 14 & 26 & 81 & $1.25 \pm 0.035^{\mathrm{Ba}}$ \\
\hline & 0.5 & 7633 & 16 & 23 & 33 & 42 & 114 & $1.49 \pm 0.028^{\mathrm{Ca}}$ \\
\hline & 2.5 & 6735 & 25 & 32 & 37 & 21 & 115 & $1.71 \pm 0.022^{\mathrm{Da}}$ \\
\hline
\end{tabular}

MN: Micronucleus; FAC: Fragmented Apoptotic Cell

B-SC: Bean-shaped cell; LN: Lobed nucleus

\section{Authors contribution}

Ayanda Opeyemi Isaac carried out the experiment, analyzed the data, and prepared the draft manuscript

Min Yang monitored and supervised the progress of the experiment, analyzed the data and reviewed the draft manuscript

Zhang Yu monitored the progress of the experiment and reviewed the draft manuscript

Jinmiao Zha designed and supervised the experiment

Acknowledgments. The authors are grateful to Third World Academy of Sciences (TWAS) and the Chinese Academy of Sciences (CAS) for granting a doctoral fellowship to Dr Isaac Ayanda to carry out this research. Many thanks to the Deputy Director of my host institution, Prof. Min Yang, Research Center for Eco-Environmental Sciences (RCEES) Beijing, China, who also doubled as my host supervisor, for granting me access to laboratory equipment and all the needed financial support in the course of this research.

\section{References}

Abdellatif A, Al-Tonsy AH, Awad ME, Roberfroid M, Khan MN. 2003. Peroxisomal enzymes and 8-hydroxydeoxyguanosine in rat liver treated with perfluorooctanoic acid. Dis Markers 19: $19-25$.

Akcha F, Hubert FV, Pfhol-Leszkowicz A. 2003. Potential value of the comet assay and DNA adduct measurement in dab (Limanda limanda) for assessment of in situ exposure to genotoxic compounds. Mutat Res 534: 21-32.

Banu BS, Danadevi K, Rahman MF, Ahuja YR, Kaiser J. 2001. Genotoxic effect of monocrotophos to sentinel species using the comet assay. Food Chem Toxicol 39: 361-366.

Banudevi S, Krishnamoorthy G, Venkatataman P, Vignesh C, Aruldhas MM, Arunakaran J. 2006. Role of $\alpha$-tocopherol on antioxidant status in liver, lung and kidney of PCP exposed male albino rats. Food Chem Toxicol 44: 2040-2046.

Butenhoff JL, Olsen GW, Fahles-Hutchens A. 2006. The applicability of biomonitoring data for perfluorooctanesulfonate to the environmental public health continuum. Environ Health Perspect 114: $1776-1782$. 
Cavas T, Garanko NN, Arkhipchuk VV. 2005. Induction of micronuclei and binuclei in blood, gill and liver cells of fishes subchronically exposed to cadmium chloride and copper sulphate. Food Chem Toxicol 43: 569-574.

Chandra P, Khuda-Bukhsh AR. 2004. Genotoxic effects of cadmium chloride and azadirachtin treated singly and in combination in fish. Ecotox Environ Safety 58: 194-201.

Ching EWK, Siu WHL, Lam PKS, Xu L, Zhang Y, Richardson BJ, Wu RSS. 2001. DNA adduct formation and DNA strand breaks in greenlipped mussels (Perna viridis) exposed to Benzo[a]pyrene: dose- and time-dependent relationships. Mar Poll Bull 42: 603-610.

De Lemos CT, Rodel PM, Terra NR, Erdtmann B. 2001. Evaluation of basal micronucleus frequency and hexavalent chromium effects in fish erythrocytes. Environ Toxicol Chem 20: 1320-1324.

Fenech M. 2000. The in vitro micronucleus technique. Mutat Res 455: $81-95$.

Fleeger JW, Carman KR, Nisbet RM. 2003. Indirect effects of contaminants in aquatic ecosystems. Sci Total Environ 317: 207-233.

Frenzilli G, Nigro M, Lyons BP. 2009. The Comet assay for the evaluation of genotoxic impact in aquatic environments. Mutat Res 681: 80-92.

Hundley SG, Sarrif AM, Kennedy GL. 2006. Absorption, distribution, and excretion of ammonium perfluorooctanoate (APFO) after oral administration to various species. Drug Chem Toxicol 29: 137-145.

Jerbi MA, Ouanes Z, Besbes R, Achour L, Kacem A. 2011. Single and combined genotoxic and cytotoxic effects of two xenobiotics widely used in intensive aquaculture. Mutat Res 724: 22-27.

Kawamoto K, Nishikawa Y, Oami K, Jin Y, Sato I, Saito N, Tsuda S. 2008. Effects of perfluorooctane sulfonate (PFOS) on swimming behavior and membrane potential of Paramecium caudatum. J Toxicol Sci 33: 155-161.

Kawamoto K, Oashi T, Oami K, Liu W, Jin Y, Saito N, Sato I, Tsuda S. 2010. Perfluorooctanoic acid (PFOA) but not perfluorooctane sulfonate (PFOS) showed DNA damage in comet assay on Paramecium caudatum. J Toxicol Sci 35: 835-841.

Kennedy Jr. GL, Butenhoff JL, Olsen GW, O'Connor JC, Seacat AM, Perkins RG, et al. 2004. The toxicology of perfluorooctanoate. Crit Rev Toxicol 34: 351-384.

Kolarević S, Knežević-Vukčević J, Paunović M, Tomović J, Gačić Z, Vuković-Gačić B. 2011. The anthropogenic impact on water quality in river Danube in Serbia: microbiological analysis and genotoxicity monitoring. Arch Biol Sci 63: 1209-1217.

Lanciotte E, Galli S, Limberti A, Givannelli L. 2004. Ecotoxicological evaluation of wastewater treatment plant effluent discharges: a case study in Parto (Tuscany, Italy). Annali Di Igiene 16: 549-558.

Lord CJ, Ashworth A. 2012. The DNA damage response and response therapy. Nature 481: 287-294.

Nwani CD, Nagpure NS, Kumar R, Kushwaha B, Kumar P, Lakra WS. 2010. Mutagenic and genotoxic assessment of atrazine-based herbicide to freshwater fish Channa punctatus (Bloch) using micronucleus test and single cell gel electrophoresis. Environ Toxicol Pharmacol 31: 314-322.

Peña-Llopis S, Ferrando MD, Peña JB. 2003. Fish tolerance to organophosphate-induced oxidative stress is dependent on the glutathione metabolism and enhanced by N-acetylcysteine. Aquat Toxicol 65: 337-360.

Rank J, Jensen K. 2003. Comet assay on gill cells and hemocytes from the blue mussel Mitylus edulis. Ecotox Environ Safety 54: 323-329.

Rocco L, Peluso C, Stingo V. 2012. Micronucleus test and comet assay for the evaluation of zebrafish genomic damage induced by erythromycin and lincomycin. Environ Toxicol 27: 598-604.
Russo C, Rocco L, Morescalchi MA, Stingo V. 2004. Assessment of environmental stress by the micronucleus test and comet assay on the genome of teleost population from two natural environments. Ecotox Environ Safety 57: 168-174.

Seacat AM, Thomford PJ, Hansen KJ, Clemen LA, Eldridge SR, et al. 2003. Sub-chronic dietary toxicity of potassium perfluorooctanesulfonate in rats. Toxicol 183: 117-131.

Singh NP, McCoy MT, Tice RR, Schneider EL. 1988. A simple technique for quantitation of low levels of DNA damage in individual cells. Exp Cell Res 175: 184-191.

Sunjog K, Gačič Z, Kolarevič S, Višnjić-Jeftić Ž, Jarić I, KneževićVukčević J, Vuković-Gačić B, Lenhardt M. 2012. Heavy metal accumulation and the genotoxicity in Barbel (Barbus barbus) as the indicators of the Danube River pollution. Sci World J 1-6.

Szefer P, Szefer K, Skwarzec B. 1990. Distribution of trace metals in some representative fauna of the Southern Baltic. Mar Poll Bull 21: $60-62$.

Takagi A, Sai K, Umemura T, Hasegawa R, Kurokawa Y. 1991. Shortterm exposure to the peroxisome proliferators, perfluorooctanoic acid and perfluorodecanoic acid, causes significant increase of 8hydroxydeoxyguanosine in liver DNA of rats. Cancer Lett 57: 55-60.

Tao L, Kannan K, Wong CM, Arcaro KF, Butenhoff JL. 2008. Perfluorinated compounds in human milk from Massachusetts, USA. Environ Sci Tech 42: 3096-3101

Udroiu I. 2006. The micronucleus test in piscine erythrocytes. Aquat Toxicol 79: 01-204

US EPA (US Environmental Protection Agency), Basic information on PFOA, 2006. Available: http://www.epa.gov/oppt/pfoa/pubs/ pfoainfo.html

Vanhulle S, Trovaslet M, Eeaud E, Lucas M, Taghavi S, van der Lelie $\mathrm{D}$, et al. 2008. Decolorization, cytotoxicity, and genotoxicity reduction during a combined ozonation/fungal treatment of dyecontaminated wastewater. Environ Sci Tech 42: 584-589.

Van der Oost R, Beyer J, Vermeulen NPE. 2003. Fish bioaccumulation and biomarkers in environmental risk assessment: a review. Environ Toxicol Pharma 13: 57-149.

Van de Vijver KI, Holsbeek L, Das K, Blust R, Joiris C, De CW. 2007. Occurrence of perfluorooctane sulfonate and other perfluorinated alkylated substances in harbor porpoises from the Black Sea. Environ Sci Tech 41: 315-320.

Vicari T, Ferraro MVM, Ramsdorf WA, Mela M, Alberto de Oliveira Ribeiro C, Cestari MM. 2012. Genotoxic evaluation of different doses of methylmercury $\left(\mathrm{CH}_{3} \mathrm{Hg}^{+}\right)$in Hoplias malabaricus. Ecotox Environ Safe 82: 47-55.

Visn-Jeftic Z, Jaric I, Jovanovic L, Skoric S, Smederavac-Lalic M, Niksevic M, Lenhardt M. 2010. Heavy metal and trace element accumulation in muscle liver and gills of the Pontic shad (Alosa immaculate Bennet 1835) from the Danube River (Serbia). Microchem J 95: 341-344.

Vuković-Gačić B, Kolarević S, Sunjog K, Tomović J, KneževićVukčević J, Paunović M, Gačić Z. 2013. Comparative response of freshwater mussels Unio tumidus and Unio pictorum to environmental stress. Hydrobiologia 735: 221-231.

Xin L, Wang J, Guo S, Wu Y, Li X, Deng H, Kuang D, Xiao W, Wu T, Guo H. 2014. Organic extracts of coke oven emissions can induce genetic damage in metabolically competent HepG2 cells. Environ Toxicol Pharmacol 37: 946-953.

Yao X, Zhong L. 2005. Genotoxic risk and oxidative DNA damage in HepG2 cells exposed to perfluorooctanoic acid. Mutat Res 587: 38 44.

Cite this article as: Ayanda IO, Yang M, Yu Z, Zha J. 2018. Cytotoxic and genotoxic effects of perfluorododecanoic acid (PFDoA) in Japanese medaka. Knowl. Manag. Aquat. Ecosyst., 419, 9. 